\title{
PENERAPAN PEMBELAJARAN KONTEKSTUAL DENGAN \\ MODEL PROBLEM BASED LEARNING
}

\author{
Titis Puspitaningrum Dewi Kartika \\ STIE Perbanas Surabaya \\ Titis_puspita@perbanas.ac.id
}

\begin{abstract}
This study aims to determine the application of contextual learning with PBL model to improve the ability of questioning and answering. This is an action research class (PTK) that was designed in two cycles. The first cycle was to carry on the topic of profit and loss statement, while the second cycle was on the rest of financial statement. The subjects of this study were accounting students at SMK Salahudin Malang. Data analysis was performed using the percentage increase of students' ability to questioning and answering of each cycle. The results show that the implementation of contextual learning with PBL model can improve the ability to questioning and answering.
\end{abstract}

Keywords: Contextual learning, PBL, questioning and answering, learning outcomes.

\begin{abstract}
Abstrak: Penelitian ini bertujuan untuk mengetahui penerapan pembelajaran konstektual dengan model PBL untuk meningkatkan kemampuan bertanya dan menjawab pertanyaan. Jenis penelitian ini adalah Penelitian Tindakan Kelas(PTK) yang dirancang dalam dua siklus. Siklus I dilaksanakan pada materi laporan laba/rugi, sedangkan siklus II pada materi laporan perubahan modal dan neraca. Subyek penelitian ini adalah siswa akuntansi di SMK Shalahuddin Malang. Analisis data dilakukan dengan menggunakan prosentase peningkatan skor hasil kemampuan bertanya dan menjawab pertanyaan serta hasil belajar tiap siklus. Hasil penelitian menunjukkan bahwa pelaksanaan pembelajaran konstektual model PBL dapat meningkatkan kemampuan bertanya dan menjawab pertanyaan.
\end{abstract}

Kata Kunci: Pembelajaran konstektual, PBL, bertanya dan menjawab, hasil belajar.

Praktek nyata yang terjadi di dunia pendidikan Indonesia yang masih saja berkembang hingga saat ini kebanyakan adalah teacher oriented dimana sebagian besar aktivitas pembelajaran masih didominasi oleh guru. Proses belajar mengajar diawali dengan mencatat materi yang akan diajarkan di papan tulis kemudian guru menjelaskannya dengan metode ceramah dan tanya jawab. Pada saat proses tanya jawab berlangsung, mayoritas siswa cenderung pasif dan hanya siswa-siswa tertentu saja yang mau merespon pertanyaan guru. Selain itu tidak banyak siswa yang bertanya apalagi menyampaikan pendapatnya secara spontan. Hal ini merupakan indikasi bahwa mereka malas untuk berfikir sebagai akses tidak terbiasa aktif dalam belajar dan terbiasa bergantung pada setiap materi yang disampaikan oleh guru. 
Salah satu faktor penyebab kurang aktifnya siswa juga terlihat dalam proses belajar mengajar adalah model pembelajaran yang digunakan guru masih konvensional. Siswa cenderung tidak mau berusaha untuk menggunakan kemampuannya secara optimal. Persepsi, minat, dan sikap siswa terhadap pelajaran tidak akan pernah optimal. Pelajaran akan lebih menarik bagi para siswa jika mereka diberi kesempatan untuk dapat belajar sendiri, kesempatan mengamati sendiri, aktif secara mandiri sehingga memungkinkan mereka dapat meresapkan bahan-bahan pelajaran. Dengan demikian, kegiatan belajar mengajar sebaiknya dirancang dalam bentuk diskusi, saling bertanya dan saling menjelaskan untuk merangsang motivasi siswa dalam belajar dan bekerjasama dengan siswa lain ataupun guru. Keterampilan yang perlu dikembangkan dalam kegiatan diskusi adalah bertanya dan merespon suatu pertanyaan. Pertanyaan diperlukan pada saat siswa kurang memahami materi pelajaran yang disampaikan dalam diskusi/pelajaran tersebut. Sebaliknya, kegiatan merespon/menjawab pertanyaan dapat diberikan jika siswa memahami materi dan mengerti maksud dari pertanyaan tersebut.

Seiring dengan perkembangan dunia pendidikan saat ini diperlukan pengajaran yang menitikberatkan pada proses pembelajaran yang lebih mengaktifkan siswa, yang tujuannya adalah untuk meningkatkan kualitas pembelajaran. Model pembelajaran yang sesuai antara lain adalah pembelajaran menggunakan pendekatan kontekstual. Pendekatan kontekstual adalah pendekatan pengajaran yang memungkinkan siswa memperkuat, memperluas, dan menerapkan pengetahuan dan keterampilan akademisnya dalam berbagai latar sekolah dan diluar sekolah untuk memecahkan seluruh persoalan yang ada dalam dunia nyata. Pembelajaran kontekstual terjadi ketika siswa menerapkan dan mengalami apa yang diajarkan dengan mengacu pada masalah-masalah riil yang berasosiasi dengan peranan dan tanggung jawab mereka sebagai anggota keluarga, anggota masyarakat, siswa, dan selaku pekerja. Salah satu model pembelajaran dari pendekatan kontekstual adalah model pembelajaran berbasis masalah (problem based learning/PBL).

Aspek penting dalam PBL adalah bahwa pembelajaran dimulai dengan permasalahan, dan permasalahan tersebut akan menentukan arah pembelajaran dalam kelompok. Kelompok siswa dituntut untuk aktif terutama mengembangkan aspek kognitifnya dalam bentuk kemampuan bertanya dan merespon pertanyaan dengan menjadikan masalah sebagai tumpuan pembelajaran, para siswa didorong untuk mencari informasi yang diperlukan untuk menyelesaikan permasalahan tersebut, yang 
kemudian akan dibahas secara bersama-sama dalam kelompok. Dengan demikian, dalam pembahasan tersebut sangat diperlukan keterampilan siswa untuk bertanya dan merespon suatu pertanyaan baik yang terjadi dalam diskusi maupun pertanyaan yang diajukan oleh guru.

Ada beberapa penelitian sejenis yang sudah pernah dilakukan berkaitan dengan penerapan pembelajaran kontekstual model PBL yang menunjukkan bahwa penerapan metode inkuiri terbimbing dalam problem based learning dengan materi Struktur dan fungsi serta gerak pada tumbuhan dapat meningkatkan motivasi dan hasil belajar siswa. Lebih lanjut, penelitian yang dilakukan oleh Khasanah (2006) menunjukkan bahwa kegiatan belajar mengajar dalam pembelajaran kontekstual dengan strategi problem based learning yang terdiri dari 5 tahapan dapat terlaksana dengan baik.

Berdasarkan hasil observasi dan wawancara peneliti dengan narasumber diperoleh informasi bahwa pembelajaran yang diterapkan selama ini, khususnya kelas AK belum pernah menggunakan metode pembelajaran kontekstual model PBL dan sistem pembelajaran yang dilaksanakan masih menggunakan sistem pembelajaran konvensional yaitu ceramah, pemberian tugas, dan tanya jawab. Rata-rata Siswa SMK Shalahuddin Malang khususnya kelas AK memiliki kemampuan yang masih kurang optimal terutama kemampuan bertanya dan merespon pertanyaan. Di samping itu, siswa kelas AK kurang memiliki motivasi dalam belajar. Hal ini dikarenakan kurangnya keterlibatan siswa secara aktif dalam proses pembelajaran, sehingga kebanyakan siswa cenderung pasif dan hanya siswa tertentu saja yang aktif dalam pembelajaran. Rendahnya motivasi belajar dan aktivitas siswa tersebut berdampak terhadap hasil belajar yang kurang memuaskan. Berdasarkan hasil studi pendahuluan di lapangan, penelitian ini bermaksud mengukur efektifitas model PBL berdasarkan kemampuan bertanya dan merespon pertanyaan pada mata pelajaran Akuntansi Keuangan di SMK Shalahuddin Malang.

Nurhadi (2004: 56) mendefinisikan PBL adalah suatu pendekatan pembelajaran yang menggunakan masalah dunia nyata sebagai suatu konteks bagi siswa untuk belajar tentang cara berfikir kritis dan keterampilan memecahkan masalah, serta untuk memperoleh pengetahuan dan konsep yang esensial dari materi pelajaran. Tahapan problem based learning menurut Nurhadi (2004:59) terdiri dari lima tahapan utama yang dimulai dengan guru memperkenalkan siswa dengan suatu situasi masalah, mengorganisasi siswa untuk belajar, pembimbing menyelidiki individu dan kelompok,mengembangkan dan menyajikan hasil karya dan diakhiri dengan 
penyajian dan analisis hasil kerja siswa. Lebih lanjut, Nurhadi (2004:57) mengatakan bahwa PBL mempunyai karakteristik atau ciri-ciri khusus, diantaranya: pengajuan pertanyaan atau masalah, keterampilan dengan disiplin ilmu lain, penyelidikan masalah autentik, memamerkan hasil karya dan kerja sama

Menurut Hasibuan (1985:62) bertanya merupakan ucapan verbal yang meminta respon dari orang yang dikenai, respon yang diberikan dapat berupa pengetahuan sampai dengan hal-hal yang merupakan hasil pertimbangan. Penjelasan diatas dapat kita pahami bahwa bertanya merupakan umpan balik bagi siswa sehingga siswa dapat mengetahui sesuatu yang belum diketahui atau sesuatu yang belum pasti. Terlihat bahwa bertanya merupakan suatu alat belajar yang sangat penting dalam proses pembelajaran. Bertanya untuk mengetahui sesuatu yang belum diketahui, memastikan informasi yang belum pasti sehingga siswa akan memperoleh konsep yang benar.

Hasibuan (1985: 19) mengatakan bahwa suatu pertanyaan yang baik ditinjau dari segi isinya, tetapi cara mengajukannya tidak tepat, akan mengakibatkan tidak tercapainya tujuan yang dihendaki. Faktor-faktor yang harus diperhatikan dalam mengajukan pertanyaan antara lain: pertanyaan hendaknya diajukan dengan jelas, serta nampak kaitannya antara jalan pikiran yang satu dengan yang lain, usahakan menyampaikan pertanyaan dengan jelas serta tidak tergesa-gesa dan pertanyaan hendaknya ditujukan ke semua siswa.

Kegiatan bertanya lazimnya selalu diikuti oleh kegiatan merespon sebagai upaya pemecahan masalah sesuai dengan pertanyaan yang telah diajukan. Melakukan kegiatan merespon sebagai upaya pemecahan masalah, diperlukan pola pikir yang reflektif. Koldberg (1985:93) menyatakan bahwa ketika suatu kelompok diskusi memecahkan masalah tentang kebingungan, keraguan atau ketidakmengertian perlu diterapkan prosedur pemecahan masalah yang ditandai dengan pola pikir reflektif, diantaranya membatasi masalah, menganalisis masalah. Merespon pertanyaan atau jawaban merupakan reaksi atau respon yang diberikan atas pertanyaan yang telah diungkapkan (Karim,1980:16). Respon pertanyaan yang dimaksudkan dalam penerapan PBL dalam penelitian ini adalah respon jawaban verbal. Respon terhadap pertanyaan perlu memberikan informasi yang diharapkan oleh penanya. Seringkali pertanyaan yang diajukan dan jawaban yang diberikan tidak berhubungan bahkan bertolak belakang. 
Parera (1987:185) mengemukakan bahwa cara mengemukakan pendapat yang baik berarti mengutarakan pendapat dalam konteks yang masuk akal. Pendapat seseorang dalam diskusi haruslah didasarkan oleh penalaran secara logis, analitis dan kreatif. Mengemukakan secara logis berarti mengemukakan pendapat secara masuk akal. Mengemukakan pendapat secara analitis diperlukan pendalaman masalah dan tidak berbelit-belit, sedangkan berfikir kreatif diantaranya mengemukakan hasil pemikiran yang baru dan tidak konvensional.

Hasil belajar merupakan puncak dari proses belajar mengajar (Dimyati dan Mudjiono,1994:11). Penilaian hasil belajar adalah proses pemberian nilai terhadap hasil belajar yang dicapai siswa dalam kriteria tertent. Hal ini mengisyaratkan bahwa objek yang dinilainya adalah hasil belajar. Hasil belajar pada hakikatnya adalah perubahan tingkah laku sebagai hasil dari proses belajar mengajar. Perubahan itu dapat berupa pengetahuan, pemahaman, keterampilan, dan sikap (Winkel,1987:2).

Hasil belajar yang dicapai siswa dapat tinggi atau rendah tergantung dari proses belajar yang terjadi dalam diri siswa. Hasil belajar akuntansi yang dicapai siswa merupakan keseluruhan hasil belajar akuntansi yang dicerminkan dalam bentuk nilai-nilai yang dicapai, baik kemampuan kognitif (pengetahuan), afektif (sikap), psikomotorik (keterampilan). Hasil belajar siswa ini merupakan salah satu indikator untuk mengukur tercapainya tujuan instruksional serta digunakan juga untuk mengetahui keefektifan proses belajar mengajar yang dilakukan oleh guru. Dengan demikian guru dapat mengetahui dan menilai kemampuannya dalam mengajar yang dapat digunakan sebagai bahan pertimbangan untuk memperbaiki proses belajar berikutnya.

\section{METODE}

Jenis penelitian ini adalah Penelitian Tindakan Kelas (Classroom Action Research). Penelitian tindakan kelas merupakan penelitian praktis yang bertujuan untuk memperbaiki suatu keadaan pembelajaran di kelas dengan melakukan tindakantindakan agar terjadi pembaharuan menuju kearah perbaikan. Tindakan yang dilakukan adalah penerapan PBL yang bertujuan untuk meningkatkan kemampuan bertanya dan merespon pertanyaan dan hasil belajar siswa kelas AK di SMK Shalahuddin Malang. Penelitian ini dirancang dalam 2 siklus, untuk siklus I ada 4 kali pertemuan sedangkan untuk siklus II terdiri dari 2 kali pertemuan. Berikut bagan alur pelaksanaan PTK yang dapat dilihat pada gambar 1. 


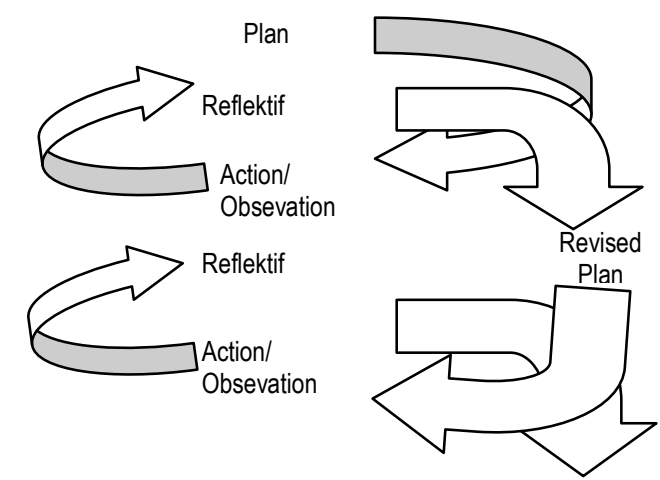

Gambar 1. Spiral Penelitian Tindakan Kelas

Definisi operasional atas istilah-istilah penting dalam penelitian ini dapat dijabarkan sebagai berikut. Problem-Based Learning (Pengajaran Berbasis Masalah) adalah suatu model pembelajaran dimana dalam penyampaian materi, siswa dihadapkan pada suatu masalah kehidupan nyata yang berhubungan dengan materi yang sedang dipelajari sehingga melalui pembelajaran ini siswa terdorong untuk berfikir kritis dan terampil dalam mencari suatu pemecahan masalah melalui tahapan-tahapan diantaranya adalah sebagai berikut (1) memahami masalah; (2) pengumpulan informasi untuk menyelesaikan masalah; (3) menentukan dan melaksanakan alternatif penyelesaian dalam sebuah laporan;(4) mengevaluasi proses dan hasil pemecahan masalah. Kemampuan bertanya merujuk pada keterampilan mengajukan pertanyaan yang optimal pada aspek tingkat pertanyaan (kualitas pertanyaan), relevansi, frekuensi dan bahasa. Kemampuan merespon merujuk pada keterampilan menanggapi pertanyaan secara tepat sesuai dengan kriteria kebenaran jawaban, relevansi, frekuensi, bahasa. Hasil belajar adalah tingkat penguasaan siswa terhadap materi selama kegiatan pembelajaran yang diukur melalui tes siklus I dan siklus II serta tes kemampuan akhir setelah mengikuti pembelajaran mata diklat Akuntansi dengan menggunakan model pembelajaran PBL.

Penelitian ini dilaksanakan di SMK Shalahuddin Malang. Subjek penelitian dalam penelitian ini adalah siswa program Keahlian Akuntansi kelas 1C AK di Salahudin Malang, dimana siswa yang mengikuti pembelajaran Akuntansi Keuangan berjumlah 28 siswa.

Instrumen yang digunakan dalam penelitian ini adalah sebagai berikut: (1) Peneliti sebagai human instrumen, yaitu perencana dan pelaksana peneliti di lapangan yaitu merancang skenario pembelajaran, rubrik penilaian, dan membuat format catatan lapangan/lembar observasi umum untuk memonitor ketercapaian rencana 
penelitian. Peneliti berfungsi sebagai pelaksana, karena peneliti menjadi pengajar pada saat penelitian berlangsung; (2) Rubrik penilaian kemampuan bertanya dan merespon pertanyaan, digunakan untuk memperoleh data perkembangan kemampuan bertanya dan merespon pertanyaan siswa selama pembelajaran berlangsung dengan menggunkaan model PBL; (3) Lembar panduan wawancara sebagai acuan wawancara kepada siswa; (4) Lembar panduan wawancara sebagai acuan wawancara kepada guru dalam hal ini bertindak sebagai fasilitator siswa dalam kegiatan pembelajaran; dan (5) Kegiatan dokumentasi digunakan untuk memberikan penguatan terhadap hasil penelitian yang telah dilakukan oleh penulis. Dokumentasi yang digunakan berupa foto kegiatan pembelajaran di kelas IC AK.

Adapun langkah-langkah analisis data adalah klasifikasi data, pengkodingan data, analisis data hasil rekaman pada catatan lapangan tentang persetujuan dan respon siswa pada tiap aspek yang dinilai dan pengelompokan tingkat keberhasilan yang dicapai siswa dalam merespon pertanyaan berdasarkan kualifikasi yang telah dicapai.

\section{HASIL DAN PEMBAHASAN}

Pembelajaran mata diklat Akuntansi Keuangan pada materi pokok bahasan laporan keuangan perusahaan dagang pada penelitian ini dilaksanakan dengan menggunakan pembelajaran PBL. Pembelajaran PBL adalah suatu strategi pembelajaran yang menggunakan permasalahan dunia nyata sebagai konteks belajar untuk berpikir kritis, problem solving, serta untuk memperoleh pengetahuan dan konsep esensial dari suatu pelajaran (Nurhadi, 2004:56). Pada pembelajaran PBL ini penulis bertindak sebagai guru mata diklat tersebut.

Permasalahan materi pokok laporan keuangan perusahaan dagang diambil dari materi pelajaran yang disimulasikan serta tugas yang diberikan secara kelompok. Siswa diminta untuk mencari dan membuat laporan keuangan perusahaan dagang. "Masalah" yang diambil merupakan masalah kehidupan nyata, dimana siswa mencari perusahaan dagang yang belum terintegrasi catatan keuangannya, dalam artian laporan keuangan perusahaan tersebut belum dalam bentuk laporan laba/rugi, laporan perubahan ekuitas, dan neraca. Berbagai masalah yang muncul dari kondisi faktual tersebut akan menjadi pembahasan untuk didiskusikan siswa bersama kelompoknya. Pemberian peluang pada siswa untuk menganalisis suatu masalah dalam pembelajaran PBL juga berfungsi sebagai sarana untuk mengembangkan keterampilan berfikir, 
bekerjasama dan meningkatkan kemampuan dalam bertanya serta merespon pertanyaan.

Pelaksanaan penelitian dalam konteks pembelajaran PBL ini terdiri dari 5 tahap, yaitu: 1) orientasi siswa pada masalah, 2) mengorganisasikan siswa untuk belajar, 3) membimbing penyelidikan secara kelompok, 4) mengembangkan dan menyajikan hasil karya, dan 5) menganalisis dan mengevaluasi proses pemecahan masalah (Nurhadi, 2004:60). Untuk lebih jelasnya diuraikan sebagai berikut. Pertama, pada tahap orientasi siswa pada masalah dijelaskan tujuan pembelajaran yang hendak dicapai, yaitu siswa dapat mendefinisikan laporan laba/rugi, laporan perubahan modal dan neraca, dapat menjelaskan akun-akun apa saja yang mempengaruhi laporan laba rugi, laporan perubahan modal dan neraca perusahaan dagang.serta dapat menyusun laporan laba rugi, laporan perubahan modal dan neraca perusahaan dagang. Siswa diminta untuk mencari dan membuat sendiri laporan keuangan tersebut. Kedua, pada tahap mengorganisasikan siswa untuk belajar, siswa dibagi menjadi 5 kelompok dan masing-masing kelompok terdiri dari 5-6 siswa. Untuk pembagian ini siswa sendiri yang memilih kelompoknya, terutama yang rumahnya saling berdekatan. Bersama dengan kelompoknya siswa mengerjakan tugas terkait dengan permasalahan yang diberikan. Ketiga, pada tahap membimbing penyelidikan secara kelompok, siswa dibimbing untuk mencari pemecahannya dan mengaitkan permasalahan dengan konsep-konsep materi yang dibahas. Pada tahap ini timbul adanya interaksi, bertukar pikiran/pendapat, bekerjasama dalam mencari pemecahan masalah antar sesama anggota kelompoknya. Bekerjasama memberikan motivasi untuk secara berkelanjutan terlibat dalam tugas-tugas kompleks dan memperbanyak peluang untuk berbagai inkuiri dan dialog untuk mengembangkan keterampilan sosial dan keterampilan berfikir (Nurhadi,2004:57). Keempat, pada tahap mengembangkan dan menyajikan hasil karya, setiap kelompok membuat hasil karya berupa laporan tertulis yang kemudian dipresentasikan didepan kelas. Sebelum dipresentasikan di depan kelas, siswa diberikan motivasi agar aktif bertanya dan merespon pertanyaan sebanyakbanyaknya, dimana nilai yang lebih dominan terletak pada keaktifan mereka dalam bertanya dan merespon pertanyaan tiap individu dalam rangka mendapatkan solusi atau titik terang dalam pemecahan masalah.Menganalisis dan mengevaluasi proses pemecahan masalah. Kelima, tahap terakhir adalah menganalisis dan mengevaluasi dengan melakukan refleksi atas proses dan pemecahan masalah yang berupa 
kesimpulan. Evaluasi dilakukan untuk mengetahui pemahaman siswa dalam menguasai materi tersebut.

\section{Kemampuan Bertanya Siswa Selama Penerapan Pembelajaran Problem Based} Learning (PBL)

Ketika proses diskusi berlangsung guru bertindak sebagai moderator, dimana peran guru disini adalah memotivasi siswa untuk bertanya dalam kegiatan diskusi tersebut. Setiap pertanyaan yang diajukan siswa, dicatat oleh guru. Jika pertanyaan dalam diskusi tersebut tidak bisa terjawab, guru mencoba memberikan pancinganpancingan atau memberikan rangsangan jawaban kepada siswa sehingga guru tidak langsung memberikan jawaban. Hal ini dapat menjadikan siswa tersebut berfikir dan tidak gampang menyerah, kecuali untuk pertanyaan pengetahuan yang memang belum mereka dapatkan/ketahui sebelumnya.

Aspek yang menjadi acuan penilaian kemampuan bertanya yang digunakan dalam penelitian ini antara lain aspek tingkat pertanyaan, aspek relevansi, aspek bahasa dan aspek frekuensi. Pada aspek tingkat kualitas pertanyaan ini ada beberapa kriteria ketercapaian yang digunakan dalam penilaian ini mulai tingkat pertanyaan dasar sampai tingkat pertanyaan lanjutan. Misalnya pertanyaan pengetahuan sampai pertanyaan tingkat analisis dengan skor 1-4. Tingkat pertanyaan yang paling banyak diajukan pada siklus I menunjukkan skor 2 (pertanyaan yang diajukan pertanyaan tingkat pemahaman) dan skor 1 (pertanyaan yang diajukan pertanyaan tingkat pengetahuan). Hal ini dikarenakan kurangnya pengetahuan mereka dalam mengembangkan pertanyaan, sehingga apa yang mereka tanyakan melihat dari buku. Tidak ada siswa yang mengajukan pertanyaan tingkat analisis, sistetis, dan evaluasi, sedangkan pada siklus II sudah ada peningkatan, skor yang paling banyak mereka peroleh adalah skor 2 (pertanyaan yang diajukan pertanyaan tingkat penerapan) dan sudah ada siswa yang bertanya tingkat analisis, sintetis, dan evaluasi.

Aspek Relevansi berisi tentang pertanyaan-pertanyaan dengan penilaian apakah relevan/sesuai dengan materi yang dipelajari saat itu. Untuk tingkat relevansi ini mulai dengan skor 1 untuk kriteria pertanyaan yang diajukan tidak relevan dengan materi yang diajarkan/didiskusikan, sampai dengan skor 4 untuk pertanyaan yang sangat sesuai dengan materi yang diajarkan. Sangat sesuai disini maksudnya adalah sangat relevan dalam artian pertanyaan tersebut memang benar-benar sesuai dengan topik yang dibahas. Misalnya yang dibahas pada saat itu tentang laporan $\mathrm{L} / \mathrm{R}$, maka 
pertanyaan yang diajukan seputar laporan tersebut. Untuk kategori relevan (skor 3), pertanyaan yang diajukan selain dari laporan laba/rugi misal laporan keuangan lain. Untuk kategori kurang relevan (skor 2), berarti pertanyaan tersebut menyimpang dari laporan keuangan tesebut tetapi masih dalam lingkup perusahaan dagang. Skor yang paling banyak diperoleh siswa adalah skor 4 (pertanyaan yang diajukan sangat relevan dengan materi yang diajarkan) baik pada siklus I maupun pada siklus II.

Pada aspek bahasa dilihat apakah bahasa/pernyataan yang digunakan siswa mudah dimengerti/dipahami orang lain dan tidak menimbulkan pengertian/makna ganda. Sangat mudah dipahami artinya pertanyaan yang diberikan tidak bertele-tele atau langsung to the point. Sedangkan kriteria ketercapaian untuk mudah dipahami adalah pertanyaan yang diberikan sedikit bertele-tele tidak langsung pada maksud yang disampaikan sehingga persepsi orang dalam menerima pertanyaan tersebut tetapi tidak menimbulkan pengertian yang berbeda-beda. Pada siklus I skor yang paling banyak diperoleh menunjukkan skor 3 (bahasa yang digunakan mudah dipahami dan tidak menimbulkan makna ganda), sedangkan pada siklus II bahasa yang mereka gunakan sangat mudah dipahami dan tidak menimbulkan makna ganda sehingga siswa dapat lebih paham dengan apa yang disampaikannya. Pada aspek frekuensi hanya dilihat seberapa banyak pertanyaan yang diberikan oleh masing-masing penanya. Pada siklus I terdapat 8 penanya sedangkan pada siklus II terdapat 13 penanya.

Hasil temuan secara umum yang didapat untuk penilaian kemampuan bertanya pada siklus I menunjukkan prosentase keberhasilan dengan tingkat kualifikasi rendah ( $<$ dari 70), dimana pada siklus I prosentase nilai rata-rata untuk kemampuan bertanya $67.9 \%$ (pertemuan I sebesar $67.5 \%$ dan pertemuan II sebesar $68.3 \%$ ). Kemampuan siswa untuk bertanya pada siklus ini masih kurang, hal ini dapat dilihat dari frekuensi mereka dalam bertanya. Pada siklus I, pertanyaan didominasi oleh dua penanya dengan skor $50 \%$ (pertanyaan yang diberikan 2-3) sedangkan penanya yang lain $25 \%$ (pertanyaan yang diberikan hanya 1). Jumlah pertanyaan pada siklus I ada 11 pertanyaan dengan 8 penanya. Hal ini dikarenakan mereka masih malu atau ragu, karena memang pembelajaran dengan diskusi ini jarang mereka dapatkan sebelumnya.

Pada siklus II persentase nilai rata-rata untuk kemampuan bertanya menunjukkan prosentase keberhasilan dengan kualifikasi sedang dimana skor rataratanya 75,89\% (pertemuan I sebesar $84.62 \%$ dan pertemuan II sebesar 67,17\%) terjadi peningkatan $7,99 \%$ dari siklus I. Frekuensi penanya sudah tidak didominasi 
seperti pada siklus I, pada siklus II ini ada satu penanya dengan frekuensi 50\% (pertanyaan yang diberikan 2-3). Pada siklus ini siswa sudah banyak yang aktif, hal ini dapat dilihat dari jumlah pertanyaan yaitu sebanyak 14 dengan 13 penanya. Berdasarkan hasil skor yang dicapai siswa dapat dilihat bahwa pembelajaran PBL dapat meningkatkan kemampuan bertanya mata diklat Laporan Keuangan Perusahaan Dagang pada pokok bahasan laporan L/R, laporan perubahan modal dan neraca siswa kelas 1 program keahlian Akuntansi Keuangan di SMK Shalahuddin Malang.

\section{Kemampuan Menjawab Pertanyaan Siswa Selama Penerapan Pembelajaran Problem Based Learning (PBL)}

Tidaklah selalu gampang bagi seseorang untuk mengutarakan pendapatnya dengan jelas agar mudah dipahami sesamanya. Apalagi pendapat itu agak komplek sifatnya karena menyangkut masalah yang rumit (Parera 1987:159). Untuk mengutarakan pendapat dengan jelas dan dimengerti, siswa perlu belajar dan melatih diri menggunakan kata-kata yang tepat dan menyusunnya menjadi kalimat yang baik. Disamping itu siswa harus dapat pula mengutarakan gagasan itu dalam urutan yang logis.

Aspek yang dinilai dalam penelitian ini ada 4 kategori, yaitu aspek kebenaran jawaban, aspek relevansi, aspek bahasa dan aspek frekuensi. Kriteria ketercapaian pada aspek kebenaran jawaban meliputi jawaban yang diberikan sangat benar, benar, kurang benar, dan salah. Sangat benar maksudnya jawaban yang diberikan sangat sempurna/lengkap dengan desertai contoh-contoh, sedangkan untuk kriteria benar jawaban yang diberikan masih kurang sempurna/lengkap. Kebenaran jawaban pada siklus I menunjukkan kriteria ketercapaian yang paling banyak adalah skor 3 (jawaban yang diberikan benar). Sedangkan pada siklus II kriteria ketercapaian menunjukkan skor yang paling banyak adalah skor 4 (jawaban yang diberikan sangat benar). Hal ini dikarenakan merespon pertanyaan sudah tidak didomonasi oleh beberapa siswa saja, sehingga mereka saling melengkapi.

Aspek relevansi pada kemampuan menjawab pertanyaan ini sifatnya sama dengan kemampuan bertanya. Skor kriteria ketercapaian banyak menunjukkan skor 4 (jawaban yang diberikan sangat relevan dengan pertanyaan yang diajukan) baik pada siklus I maupun siklus II. Pada aspek bahasa, bahasa yang digunakan menunjukkan kriteria ketercapaian dengan skor 3 (bahasa yang digunakan mudah dipahami dan tidak menimbulkan makna ganda) baik pada siklus I maupun siklus II. Pada aspek 
frekuensi, pada siklus I terdapat 8 siswa yang menjawab pertanyaan sedangkan pada siklus II ada 14 siswa yang menjawab pertanyaan.

Hasil penelitian secara umum mengenai kemampuan menjawab pertanyaan pada siklus I menunjukkan prosentase keberhasilan dengan tingkat kualifikasi sedang (70$79 \%$ ) dengan prosentase nilai rata-rata sebesar 77,69\% (pertemuan I sebesar $71.6 \%$ dan pertemuan II sebesar 83,78\%). Kemampuan siswa untuk menjawab pertanyaan pada siklus I masih kurang, Hal ini dapat dilihat dari jumlah siswa yang menjawab masih didomonasi oleh dua siswa dengan frekuensi $75 \%$ (jawaban yang diberikan antara 4-5) dan satu siswa dengan frekuensi 50\% (jawaban yang diberikan 2-3) dari total 15 siswa. Pada siklus I siswa cenderung malu untuk mengutarakan pendapatnya, mereka lebih berani menjawab dengan serentak dari pada mengacungkan tangannya untuk menjawab sendiri.

Pada siklus II terjadi peningkatan kemampuan menjawab pertanyaan sebesar 9,06\% dari siklus I. Pada siklus II ini menunjukkan prosentase keberhasilan dengan kualifikasi tinggi (> dari 80) dengan prosentase nilai rata-rata sebesar $86,75 \%$ (pertemuan I sebesar $82.5 \%$ dan pertemuan sebesar II 91\%). Untuk frekuensi menjawab pertanyaan menunjukkan skor rata-rata 50\% untuk tiga penjawab dari 17 siswa yang menjawab. Hal ini berarti siswa yang lainnya sudah mulai banyak yang aktif dan berani untuk mengemukakan pendapatnya.

Berdasarkan hasil skor yang dicapai siswa dapat dilihat bahwa pembelajaran PBL dapat meningkatkan kemampuan menjawab pertanyaan untuk mata diklat Laporan Keuangan Perusahaan Dagang pada pokok bahasan laporan L/R, laporan perubahan modal dan neraca siswa kelas 1 program keahlian Akuntansi Keuangan di SMK Shalahuddin Malang.

\section{Hasil Belajar Siswa dalam Pembelajaran Problem Based Learning (PBL)}

Hasil belajar mencerminkan kemampuan siswa dalam mencapai suatu kompetensi dasar. Hasil belajar berfungsi sebagai petunjuk tentang perubahan tingkah laku yang akan dicapai oleh siswa sehubungan dengan kegiatan pembelajaran yang dilakukan. Hasil belajar berbentuk pengetahuan, keterampilan, dan sikap dan untuk mengetahui hasil belajar siswa salah satunya dengan cara pemberian tes pada siswa.

Tes ini dilakukan pada tiap siklus pada kegiatan pembelajaran, yang mana dalam tes tersebut harus dikerjakan sendiri oleh siswa, siswa dilarang bekerjasama, maupun berdiskusi. Soal tes siklus I terdiri dari 4 soal uraian, soal tes siklus II terdiri 
1 soal uraian sedangkan tes sumatif tediri dari 20 soal pilihan ganda, sedangkan waktu untuk mengerjakan masing-masing 45 menit.

Hasil penelitian ini menunjukkan bahwa rata-rata skor pada siklus I mengenai sub pokok bahasan laporan laba/rugi yaitu 80 dengan nilai tertinggi 100 dan jumlah siswa yang tuntas belajar (skor $\geq 70$ ) sebanyak 21 dari 26 siswa atau 80,76\% siswa yang tuntas belajar sedangkan rata-rata skor pada siklus II mengenai sub pokok bahasan laporan perubahan modal dan neraca adalah 83.4 dengan nilai tertinggi 100 dan jumlah siswa yang tuntas belajar (skor $\geq 70$ ) sebanyak 24 dari 27 siswa atau $88,89 \%$ siswa yang tuntas belajar. Untuk tes kemampuan akhir bahwa rata-rata skor tes ini mengenai sub pokok bahasan laporan laba/rugi, perubahan modal dan neraca yaitu 80.8 dengan nilai tertinggi 100 dan jumlah siswa yang tuntas belajar (skor $\geq 70$ ) sebanyak 23 dari 25 siswa atau 92\% siswa yang tuntas belajar.

Berdasarkan hasil belajar pada keseluruhan tes dapat dilihat bahwa pembelajaran PBL dapat meningkatkan hasil belajar mata diklat Laporan Keuangan Perusahaan Dagang pada pokok bahasan laporan L/R, laporan perubahan modal dan neraca siswa kelas 1 program keahlian Akuntansi Keuangan di SMK Shalahuddin Malang.

\section{SIMPULAN}

Hasil penelitian menunjukkan bahwa pelaksanaan pembelajaran konstektual model PBL dapat meningkatkan kemampuan bertanya, kemampuan menjawab pertanyaan serta hasil belajar.

\section{DAFTAR RUJUKAN}

Dimyati, Mudjiono. 1994. Belajar dan Pembelajaran. Jakarta. Proyek Pembinaan dan Peningkatan Mutu Tenaga Kependidikan. Direktorat Jenderal Pendidikan Tinggi Departemen Pendidikan.

Hasibuan. 1985. Proses Belajar Mengajar. Bandung: Rosadakarya.

Karim, Mariana. 1980. Teknik Bertanya dalam Pengajaran Bahasa. Jakarta: Depdikbud.

Khasanah, Uswatun. 2006. Penerapan Srategi PBL dalam Pembelajaran Kontekstual pada materi pokok larutan elektrolit dan non elektrolit siswa kelas X SMAN 8 Malang. Skripsi tidak diterbitkan. Malang: Jurusan Kimia, FMIPA, UM. 
Nurhadi. 2004. Kurikulum, Pertanyaan dan Jawaban.Jakarta: PT. Gramedia Widia Sarana (Grasindo).

Parera, Jos Daniel. 1987. Belajar Mengemukakan Pendapat, Standar, Logis, Pragmatik. Jakarta: Erlangga.

Winkel, W.S. 1987. Pikologi Pendidikan dan Evaluasi Hasil Belajar. Jakarta: Gramedia. 